\title{
In Using Leaders as Insider Witnesses Without Prosecuting Them, the Special Court for Sierra Leone May Have Legitimised Impunity
}

\author{
Ishmail Pamsm-Conteh \\ LLB (Law); University of Sunderland, MSc. (Criminal Justice Policy); \\ London School of Economics, PhD Candidate; University of Leeds, UK
}

Doi: 10.19044/esj.2017.c1p13 URL:http://dx.doi.org/10.19044/esj.2017.c1p13

\begin{abstract}
There is a determination on the part of the international community that perpetrators of crimes during conflicts should not escape punishment for the roles they play during crises by either committing these offences themselves or by authorising their commission for such actions. Since most crimes are not documented, which makes it hard to acquire the proof or evidence required for conviction, the courts or tribunals rely on the testimony of individuals who witnessed the crimes that have been committed. Such individuals are known as insider witnesses. In cooperating with the prosecution, if they themselves had been among the perpetrators or part of the accomplices, they are sometimes given, though not in all cases, a reduced sentence, as part of the plea bargain with the prosecution. However, agreeing to testify does not exempt one from punishment. This is because there is an underlying principle that individuals who commit such crimes must be held accountable; the same principle is aimed at ending impunity for crimes committed during conflicts such as these that offend international law.

The Mandate of Special Court for Sierra Leone was to prosecute those individuals who bear the greatest responsibility..., including those leaders who, in committing such crimes, have threatened the establishment of and implementation of the peace process in Sierra Leone. ${ }^{1}$ However, Prosecutors at various stages of the trials engaged some of these leaders as insider witnesses, without prosecuting them. Consequently, these leaders evaded punishment for their alleged crimes. In this process, the Special Court may have legitimised impunity.
\end{abstract}

Keywords: Leaders, insider witnesses, impunity, accountability

* LLB (Law); University of Sunderland, MSc. (Criminal Justice Policy); London School of Economics, PhD Candidate; University of Leeds, UK

${ }^{1}$ Article 1(1) of the Statute of the Special Court for Sierra Leone 


\section{Introduction}

Sierra Leone was ravaged by a civil war that lasted between 1991 and 2002 , resulting in an estimated 70,000 casualties and 2.6 million displaced persons. ${ }^{2}$ The war was characterized by widespread atrocities, including forced recruitment of child soldiers, extensive incidences of rape, sexual slavery and amputation of limbs. ${ }^{3}$ Various peace processes, facilitated by the international community, which were aimed at ending the war between the Sierra Leone Government and the main protagonists, the Revolutionary United Front (RUF) rebel group, were unsuccessful. These failed peace processes include the Abidjan Peace Agreement reached on $30^{\text {th }}$ November, 1996, which stipulated that a general amnesty be granted to the RUF rebel group, ordering them to disarm and form a political party. ${ }^{4}$ The date of the Abidjan peace agreement was of great significance, as the United Nations Security Council accepted it as the temporal jurisdiction for the Court, being the first comprehensive peace agreement that was reached between the RUF rebels and the Government of Sierra Leone.

Other protagonists in the conflict were members of the Armed Forces Revolutionary Council (AFRC), an offshoot of the main Sierra Leone Army (SLA). This group later formed a military government with the RUF rebels after the overthrow of the Sierra Leone People's Party (SLPP) civilian government of President Tejan Kabba by a military coup on $25^{\text {th }}$ of May, 1997. Another group was the civil militia known as the Civil Defence Forces (CDF), which was fighting on the side of the SLPP government. There was also the international peace keeping troop under different nomenclatures, such as ECOWAS Monitoring Group (ECOMOG), United Nations Observer Mission in Sierra Leone (UNOMSIL), and the United Nations Mission in Sierra Leone (UNAMSIL) peace keepers.

This article aims at discussing that in using leaders as insider witnesses without prosecuting them the Special Court for Sierra Leone may have legitimised impunity.

${ }^{2}$ Mary Kaldor with James Vincent, 'United Nations Development Programme Evaluation Office', EVALUATION OF UNDP ASSISTANCE TO CONFLICT AFFECTED COUNTRIES; CASE STUDY SIERRA p.4<http://web.undp.org/evaluation/documents/thematic/conflict/SierraLeone.pdf> accessed 18 August 2017

3 ibid

${ }^{4}$ UNITED STATES INSTITUTE OF PEACE. Peace Agreement Digital Collection, Sierra Leone>> Peace Agreement.https://www.usip.org/sites/default/files/file/resources/collections/peace_agreeme nts/sierra_leone_11301996.pdf, accessed 18 August 2017 


\section{Background to Establishing the Special Court for Sierra Leone}

The Special Court for Sierra Leone (hereinafter referred to as the Court, the Special Court) was created out of a letter dated the $12^{\text {th }}$ of June, 2000, when President Kabba in his address to the President of the UN Security Council and the international community requested for the establishment of a "Special Court for Sierra Leone." The first paragraph of the letter partly reads thus:

"On behalf of the Government and people of the Republic of Sierra Leone, I write to request you initiate a process whereby the United Nations would resolve on the setting up of a special court for Sierra Leone. The purpose of such a court is to try and bring to credible justice those members of the Revolutionary United Front (RUF) and their accomplices responsible for committing crimes against the people of

Sierra Leone and for the taking of United Nations peacekeepers as hostages. ${ }^{6}$

This request was met with the Council's favourable response and within 8 weeks. On the $14^{\text {th }}$ of August, 2000, the United Nation Security Council passed a Resolution 1315(2000), ${ }^{7}$ instructing the United Nations Sectary General of the time, Kofi Anan, to negotiate an agreement with the Kabba government that should be aimed at establishing the Court. On the $16^{\text {th }}$ January, 2002, a formal bi-lateral agreement was signed in Freetown between the United Nations, represented by its Assistant Secretary-General for Legal Affairs, Hans Corell, and the Government of Sierra Leone represented by its Attorney General and Minister of Justice, Solomon Berewa. ${ }^{8}$ Annexed to the agreement was the Statute of the Court. ${ }^{9}$ This agreement set out the legal framework for a mixed Court, which featured both local and international elements, whilst taking into account some of the experiences of the already functional sister tribunals of the International Criminal Tribunal for Yugoslavia (ICTY) and the International Criminal Tribunals for Rwanda (ICTR). For example, the Rules of Procedure and Evidence (RPE) for the

5 President of the Republic of Sierra Leone, Annex to the letter dated 12 June 2000, addressed to the President of the Security Council, U.N. Doc. S/2000/786/ < http://www.rscsl.org/Documents/Establishment/S-2000-786.pdf > accessed 3 July 2017

${ }^{6}$ ibid

${ }^{7}$ The United Nations Security Council Resolution, '1315(2000) UN Doc. S/RES/1315(2000), 14August 2000. http://www.rscsl.org/Documents/Establishment/S-Res-1315-2000.pdf accessed 12 January 2017

${ }^{8}$ William Schabas`The UN International Criminal Tribunals The former Yugoslavia, Rwanda and Sierra Leone (First Published 2006, Cambridge University Press) pp, 38-39

${ }^{9}$ The Agreement between the GOSL and the UN, on establishing the court was signed on 16 January 2002, came into effect on 12 April 2002, <http://hrlibrary.umn.edu/instree/SCSL/SierraLeoneUNAgreement.pdf >accessed 3 July 2017 
Court under Article 14(1) were mutatis mutanda to the ICTR, as a result of this experience. ${ }^{10}$ Whilst the ICTY and ICTR were established under a Chapter VII mandate of the UN Security Council, ${ }^{11}$ the Court was established in similarity to the Extraordinary Chambers in the Courts of Cambodia, as a bilateral agreement between the UN and the individual countries.

\section{The Global Community's Effort to End Impunity after Conflicts}

Since the Nuremberg Trials of 1945 and 1946, there has been a concerted effort, whether by treaty, customary law practice, resolutions or through legislation, by the global community and other organisations, including the $\mathrm{UN}$, human right organisations, civil right activists and the likes, to hold to account individuals who commit crimes during conflicts. This position is reflected in Rule 158 (Prosecution of war crimes) of International Humanitarian Law (IHL), which states; "States must investigate war crimes allegedly committed by their nationals or armed forces, on their territories, and if appropriate, prosecute the suspects." 12

This position has been unequivocal as was reiterated in the speech by the former UN Sectary General, Ban Ki Moon, on $31^{\text {st }}$ of May 2010:

"In this new age of accountability, those who commit the worst of human" crimes will be held responsible. Whether they are rank and file foot soldiers or military commanders, whether they are lowly civil servants following orders, or top political leaders, they will be held accountable." ... Let it be known as the place where the international community, coming together in concert, closed the door on the era of impunity and, acting in concert, ushered the age of accountability." 13

It was, therefore, no surprise that after the Balkans war and the Rwandan Genocide, in the late 1980s to early 1990's, the world appalled by the atrocities committed during those conflicts, the UN and the international community established the ICTY in 1993 and the ICTR in 1994, respectively. The establishment of the International Criminal Court through the Rome Statute, which was enforced on $1^{\text {st }}$ July, 2002, and the various ad hoc courts

10 Article 14(1) of the Statute of the Court, reads, "The Rules of Procedure and Evidence of the International Criminal Tribunal for Rwanda obtaining at the time of the establishment of the Special Court shall be applicable mutatis mutandis to the conduct of the legal proceedings before the Special Court."

${ }_{11}$ Schabas (n 8), p. 49

12 International Humanitarian Law, Data Base, < https://ihl-databases.icrc.org/customaryihl/eng/print/v1_cha_chapter44_rule158 $\geq$ accessed 17 August 2017

${ }^{13}$ United Nations Secretary General Bank Ki-Moon, Address to the Review Conference on the International Criminal Court,KampalaUgandaon31May2010<http://www.un.org/africarenewal/web-features/secretarygeneral\%E2\%80\%99s-\%E2\%80\%9C-age-accountability\%E2\%80\%9D-address-icc-reviewconference $\geq$ accessed 17 August 2017 
elsewhere in the world, are all geared towards this same goal of; ending impunity and holding individuals to account for the crimes they commit. Considering the heinous crimes that were committed in Sierra Leone, it was inevitable that those individuals responsible for perpetuating such crimes would be held to account eventually.

\section{The key Objective of United Nations Security Council Resolution 1315 (2000)}

The Resolution at paragraph 6, states, “...the Special Court shall have personal jurisdiction over persons who bear the greatest responsibility..., including those leaders who, in committing such crimes, have threatened the establishment of and implementation of the peace process in Sierra Leone." 14

The UN Sectary General, during the negotiations, with the UN Security Council in establishing the Court had accepted that "persons who bear the greatest responsibility" did not limit jurisdiction to political and military leaders only, instead going by the determination of the phrase, it falls initially to the Prosecutor and ultimately to the Court itself. ${ }^{15}$ As the phrase was not defined in the UN Resolution, the matter for interpretation of the phrase, "persons who bear the greatest responsibility," came before Trial Chamber I through a defence motion about the Court's lack of personal jurisdiction under Article 1(1), ${ }^{16}$ in Prosecutor v. Fofana. ${ }^{17}$ His defence counsel submitted that the Court did not have personal jurisdiction over Fofana, because the suspect fell outside the category of persons "who bore the greatest responsibility" for alleged violations of serious international humanitarian law contained in his indictment. In its ruling, the Chamber held: "While those 'most responsible' obviously include the political or military leadership, others in command authority down the chain of command may also be regarded as 'most responsible' judging by the severity of the crime or its massive scale... [I]t must be seen, however, not as a test criterion or a distinct jurisdictional threshold, but as guidance to the Prosecutor in the adoption of a prosecution strategy and in making decisions to prosecute individuals"18

\footnotetext{
${ }^{14}$ This wording in the Article 15(1) of the Statute do not describe an element of the crime, but rather provided guidance to the Prosecutor in determining his or her prosecutorial strategy. see UN Doc S/2000/40/paragraph 3.

15 Kirsten Ainley, Rebekka Friedman and Chris Mahony`Evaluating Transitional Justice, Accountability and Peacebuilding in Post- Conflict Sierra Leone, (First Published 2015 by MACMILLAN PALGRAVE) p. 87

16 (n 1)

${ }^{17}$ Prosecutor v. Fofana, Case No. SCSL-04-14-PT (Preliminary Defence Motion- Matters Requiring Factual Determination), 3 March 2004

${ }^{18}$ Prosecutor v. Fofana, Case No. SCSL-04-14-PT. 3 March 2004, para 22
} 
In other words, the Prosecutor's responsibility in investigating and prosecuting 'those who bear the greatest responsibility' should not only include the political or military leaders, but also those who committed severe and grave offences or the massive scale of the offences, as a corollary to the UN Sectary General's assertion of 'most responsible'.

The Court only indicted thirteen individuals; two died before they stood trial, one died during the trial, and the fate of another is still unknown. At the end, the Court only prosecuted nine individuals. ${ }^{19}$ It has been argued that because only a few individuals faced prosecution, the Court underachieved its mandate. The reason for this emanates from the fact that, considering the war that lasted for eleven years together with the scale and brutality of the atrocities committed, the general expectation of Sierra Leoneans was that more people should have been prosecuted. The counter argument to this was that the Court was meant to last for only a few years and the funding structure also influenced the number of persons prosecuted.

\section{Defining an Insider Witness}

During any post conflict period, it is usually very difficult to acquire hard evidence to assist in the prosecution of alleged perpetrators, as these atrocities are hardly documented. The courts or tribunals would therefore rely on insiders to provide valuable information regarding the alleged crimes committed and the identity of the perpetrators who committed them. Persons who were close to the accused are called 'insider witnesses', as explained by the ICTY; "The evidence gained from their testimony is often crucial for the establishing of the degree of responsibility of the accused." 20 Former Prosecutor at the ICTY and ICTR, Carla Del Ponte, also explains, "Insider witnesses are persons in a position to provide crucial, high grade information about political and military decision making, because they had witnessed events at close proximity to the decision makers." ${ }^{21}$ Anne Marie de Brueller and Allette Smuelle also stated, "...Insider witnesses are usually accomplices to the crimes with which the accused were charged." 22

${ }_{19}$ The Special Court for Sierra Leone and the Residual Special Court for Sierra Leone, Website http://www.rscsl.org/index.html accessed 17 August 2017

${ }^{20}$ United Nations International Criminal Tribunal for the former Yugoslavia. Website page on`Witnesses`http://www.icty.org/en/about/registry/witnesses accessed 30/12/2016

${ }^{21}$ Carla Del Ponte with Chuck Sudetic, 'Madame Prosecutor Confrontations with Humanity's Worst Criminals and the culture of Impunity`(Published 2008, Other Press New York) p. 128

${ }^{22}$ Anne Marie de Brouwers and Alette Smeulers, The Elga Companion to the International Criminal Tribunal of Rwanda. (Edward Elgar Publishers 2016),p. 248 
Prosecutors David Crane, ${ }^{23}$ Stephen Rapp ${ }^{24}$ and Brenda Hollis, ${ }^{25}$ were United States (US) citizens, who also happened to be the lead Prosecutors as at when the trials began and at different stages of the judicial activities of the Special Court. It should be safe to assume that their prosecutorial strategy might have been influenced by the US judicial system. Therefore, it is thus worth mentioning of the US policy on insider witness. It states thus:

"This policy recognizes that persons who have committed serious crimes should not be allowed to avoid all penal sanctions by agreeing to testify. At the same time, the policy gives the "insider" hope that at the end of the process, the insider will still have the opportunity to start a new life. It is the collective judgment of the United States that the cost of allowing reduced sentences for cooperation against leaders of the criminal organization is justified by the need to defeat the criminal organizations that pose such serious threat to civil society." 26

This policy would be referred to again as the paper is discussed.

\section{The Use of Leaders as Insider Witnesses at the Court}

The Prosecutor's strategy at the Court of using leaders as insider witnesses, without prosecuting them, has come under scrutiny in the context of prosecuting those "who bear the greatest responsibility," for these reasons: (A) The competence of the Court, which was to prosecute individuals who committed grave or serious offences, and the leaders who in committing offences threatened the establishment and implementation of the peace process in Sierra Leone; (B) by cooperating with the prosecution, individuals should not be allowed to escape punishment for their alleged crime, as encapsulated in the US policy on insider witness already quoted.

Amongst the insider witnesses who testified at the Court were; Gibril Massaquoi, in Prosecutor $v$ Sesay, Kallon and Gbao (RUF Trials), ${ }^{27}$ George Johnson aka. Junior Lion, in Prosecutor v Brima, Kamara and Kanu (AFRC Trials), ${ }^{28}$ Albert Nallo in Prosecutor $v$ Norman, Fofana and Kondewa (CDF Trials), ${ }^{29}$ and Moses Blah in the Prosecutor $v$ Taylor (Charles Taylor Trial). ${ }^{30}$ The first two mentioned individuals did not only occupy leadership roles in

23 Prosecutor April 2002 to July 2005

${ }^{24}$ Prosecutor January 2007 to September 2009

${ }^{25}$ Prosecutor February 2010 to 2013

${ }^{26}$ Robert Courtney III, ' INSIDERS AS COOPORATING WITNESES: OVERCOMING FEAR AND OFFERING HOPE`p.39. http://www.unafei.or.jp/english/pdf/PDF_GG4_Seminar/Fourth_GGSeminar_P36-46.pdf accessed 16 August 2017

${ }^{27}$ Prosecutor v Sesay, Kallon and Gbao (RUF Trial), Case No. SCSL-04-15

${ }^{28}$ Prosecutor v Brima, Kamara and Kanu (AFRC Trial) Case No. SCSL -04-16

${ }^{29}$ Prosecutor v Norman, Fofana and Kondewa (CDF Trial), Case No. SCSL 04-14

${ }^{30}$ Prosecutor $v$ Charles Taylor (Taylor Trial), Case No. SCSL 03-01 
their various organisations, but they also admitted or were found to have taken part in the crimes for which others were being prosecuted. This is supported by the Judgement in the RUF trials, which reads:

"...These insider witnesses were themselves high ranking officers in the RUF or AFRC. Many of these witnesses were key participants to the crimes alleged in the Indictment, and may be considered to be coperpetrators or accomplices. The Chamber reiterates that the Appeals Chamber has clarified that such persons may be considered accomplices even if they have not been charged with any criminal offences." "31

It is against this backdrop that the question is asked, whether the Prosecutor's strategy was robust enough, by using leaders, who have been accused of committing alleged crimes, to serve as insider witnesses, whilst evading prosecution. Their alleged crimes and roles as insider witnesses are now considered in turns:

\section{Gibril Massaquoi}

The Country's Truth and Reconciliation Commission (TRC) in its final report found that, Massaquoi approximately executed 24 innocent people in the Pujehun district. ${ }^{32}$ The report further states, "Sankoh's "Special Assistant", Gibril Massaquoi, personally fuelled the tensions surrounding the UNAMSIL hostage-taking crisis. He was a central part of the chain of command of the RUF. Massaquoi bears an individual share of the responsibility for the deterioration in the security situation in Sierra Leone." 33 Massaquoi served as a key witness at the RUF trials, and his testimony was significant to the successful conviction of those RUF leaders who were prosecuted by the Court, even though he himself was a leader within the RUF rebel movement as was found in the TRC report.

\section{George Johnson}

From the AFRC Trial, this part of the transcript of George Johnson's testimony is hereby reproduced. His answers have been highlighted in bolded fonts for emphasis:

\section{A. Yes, his a.k.a. name was Gullit.}

$2 \mathrm{Q}$. You said you were appointed to the position of provost

3 marshal by Alex Tamba Brima in Mansofinia. Before that, what

4 position had you held?

31 RUF Trial Judgement SCSL-04-15-T, delivered 2 March 2009, para. 539

32 TRC report. Volume two, chapter two, at paragraph 156.http://www.sierraleonetrc.org/index.php/view-report-text-vol-2/item/volume-twochapter-two?category_id=20 accessed 05 January 2017

33 ibid TRC Report para. 166 
10:58:02 5 A. Before that, I was still the chief security officer to 6 Ibrahim Bazzy Kamara in Kono. As a lieutenant.

7 Q. Moving on, to still in the year 1998, were there any

8 further alterations to the appointments you held in that year

9 that you are able to recall?

10:58:32 10 A. Yes, at Camp Rosos, I was given a battalion to command.

$11 \mathrm{Q}$. Who gave you the battalion to command?

12 A. Alex Tamba Brima, a.k.a Gullit.

13 Q. Do you remember the battalion number?

14 A. It was the 4th Battalion. ${ }^{34}$

His testimony continues:

19 A. After the burial of SAJ Musa, we only spent two days there. 09:59:47 20 Q. Where did you go after that?

$21 \mathrm{~A}$. We went into the Peninsular Hills to Hastings.

22 Q. Did anything happen at Hastings?

23 A. Yes, Hastings was first attacked.

24 Q. Do you know who led that attack?

10:00:04 25 A. It was led by me.

26 Q. What was the purpose of that attack?

$27 \mathrm{~A}$. The purpose of the attack was for us to go and get more 28 arms and ammunitions from the Nigerians because it was their 29 headquarter. ${ }^{35}$

It is hereby appropriate to again reiterate that President Kabba's request to the UN for establishing the Court, amongst other reasons, was to prosecute those who attacked and kidnapped the international peace keepers. The offence of direct intentional attack on peace keepers ${ }^{36}$ was to become a specific offence under international humanitarian law, for the very first time at an international court.

\section{Albert Jusu Nallo}

Albert Jusu Nallo, as Deputy National Coordinator, occupied a high position in the CDF hierarchy. At the CDF trial, he testified against his subordinate, Allieu Kondewa. The usual practice according to previous international tribunals was for those persons who occupy lower position in the cadre of the organisation to testify against their leaders, and not the other way round. In the event where leaders testify against their subordinates, they

${ }^{34}$ AFRC Trial, Case No. SCSL-2004-16-T, 15 September 2005, p.10

${ }^{35}$ AFRC Trial, Case No. SCSL-2004-16-T, 15 September 2005, p.14

${ }^{36}$ Article 4(b) of the Statute of the Special Court for Sierra Leone 
should not be excused from punishment, as the case of Jean Kambanda at the ICTY, which has been discussed below, would show. Tim Kelsall wrote, "...He (Nallo) claimed to have sat with Moinina Fofana ${ }^{37}$ to plan strategies for war operations and that he wrote down these strategies and passed it to others to implement." 38 As a planner and a leader, even if he did not physically commit an offence, but being under command and bearing superior responsibility, he should have been captured under the umbrella of, "those who bear the greatest responsibility," for the crimes under the jurisdiction of the Court.

\section{Moses Blah}

At the Charles Taylor trial, the use of his Vice President, Moses Blah, as an 'insider witness` should be justified because of three reasons: (A) He was subordinate to Charles Taylor. (B) It was alleged that he (Charles Taylor) had executed most of the members of his inner circle, and there were very few if any who would have been in the position to provide the information the Court sought in order to carry a successful conviction. ${ }^{39}$ Indeed, the prosecution claims that some members of the accused's inner circle were murdered because they were aware of the crimes perpetrated by the accused and they stood as potential threats in exposing him (Charles Taylor). ${ }^{40}$ Moreover, many individuals associated with the Taylor regime were afraid to testify for the defence due to the fear of being subjected to a UN-imposed travel ban and seizure of their assets had they attended the Court. ${ }^{41}$ (C) There was no evidence suggesting that Blah had committed crimes that fell within the jurisdiction of the Court for which he was to be prosecuted.

It is hereby appropriate to draw a few comparisons on how the Court engaged insider witnesses, as opposed to the sister tribunals of the ICTY and ICTR.

At the ICTY for example, the following individuals served as insider witnesses but they were not exempted from prosecution:

Miroslav Bralo was a member of a Military Police unit of the Croatian Defence Council. Bralo committed a range of appalling crimes and was convicted of killing five people and of assisting the killing of 14 Bosnian Muslim civilians, nine of whom were children. The Trial Chamber believed

\footnotetext{
${ }^{37}$ Moninina Fofana was one of the Accused Persons in the CDF Trial

38 TIM KELSALL, CULTURE UNDER CROSS-EXAMINATION: INTERNATIONAL JUSTICE AND THE SPECIAL COURT FOR SIERRA LEONE (Published 2009, Cambridge University Press,) P.99

39 Gill Wigglesworth The End of Impunity? Lessons from Sierra Leone` page 820 http://web.ics.purdue.edu/ wggray/Teaching/His300/Handouts/Wigglesworth-SierraLeone.pdf accessed 12 August 2017

${ }^{40}$ Wigglesworth (n 39) p.820

${ }^{41}$ ibid
} 
that it was noteworthy when he admitted to crimes of which he was not originally charged with and that he made efforts to atone for his crimes by engaging in community work and assisting in the location of the remains of some of his victims. He was subsequently sentenced to 20 years' imprisonment. $^{42}$

Dragan Zelenović was a Bosnian Serb soldier and de facto military policeman in the town of Foča, Bosnia and Herzegovina in 1992. Zelenović raped and tortured a number of detained Muslim women and girls, including a 15-year-old. Women who resisted his sexual assaults were threatened with death or were beaten. As part of the plea agreement, he agreed to provide truthful and complete information and to testify at any proceedings before the ICTY. He was later sentenced to 15 years' imprisonment. ${ }^{43}$

Predrag Banović was a guard at the Keraterm detention camp in Prijedor, Bosnia and Herzegovina in 1992. He participated in the abuse and persecution of non-Serb detainees within the camp. He murdered five prisoners as a result of his participation in beatings and also beat up 27 detainees with baseball bats, truncheons, cables, and iron balls. Banović was sentenced to 8 years' imprisonment. ${ }^{44}$ In his guilty plea statement, he states, "I feel sorry for all the victims, and I curse my own hands for having inflicted pain in any way on innocent people. I wish my sincere words to be understood as a balm for those wounds and as a contribution to the reconciliation of all people in Prijedor and the restoration of the situation that existed before the war." 45

At the ICTR, the case of former Prime Minister Jean Kambanda, who was prosecuted as a leader is worthy of mentioning. He had testified against others including former ministers, government officials including members of the military. ${ }^{46} \mathrm{He}$ was found guilty of the crimes he committed and sentenced to life imprisonment. The Trial Chambers in passing Judgment stated this:

"The Chamber recalls as aforementioned that the Tribunal was established at the request of the government of Rwanda; and the Tribunal was intended to enforce individual criminal accountability on behalf of the international community, contribute in ensuring the effective redress of violence and the culture of impunity, and foster national reconciliation and peace in Rwanda. (Preamble, Security Council resolution 955(1994))."

\footnotetext{
42 Prosecutor v Miroslav Bralo Case No. IT-95-17 820

${ }^{43}$ Prosecutor v Dragan Zelenovic Case No. IT-96-23/2

${ }_{44}$ Prosecutor v Predrag Banovic Case No. IT-02-65-1

45 ibid

46 Prosecutor v Jean Kambanda, Case No. ICTR 99-54-A-T

47 ibid, Trial Judgement, 22 January 2004, para. 59
} 
Another example is the case of Prosecutor v Omar Serushago ${ }^{48}$ who did not only volunteer to the authorities; he also cooperated with the Prosecutor[RT1]. He was sentenced to 15 years in prison, despite his surrender and corporation and his not being a leader, but a middle level perpetrator. Yet another example is the case of Prosecutor $v$ Georges Ruggiu. Mr Ruggiu who cooperated with the Prosecutor as well and entered a guilty plea earlier in his trial, and also testified against others; notwithstanding that fact, he received a 20-year prison sentence.

Suffice it to say, it is even possible that Massaquoi, Johnson, and Nallo were rewarded by the Court when they were provided with incentives to serve as witnesses and for subsequent relocation together with their families out of the country as part of the Witness and Victim Services (WVS) programme. ${ }^{49}$ The basis for suggesting these lies or rests in the Court's policy on financial incentives for witnesses who testify ${ }^{50}$ and as well as the Court's policy on relocation of witnesses to a third country after testifying for the prosecution. ${ }^{51}$

The question remains, why would the Court, instead of prosecuting those leaders for their individual participation in the alleged committed crimes, allow them to evade prosecution? When in the Court's own decision in Prosecutor $v$ Taylor, ${ }^{52}$ it had stated that:

"By reaffirming in the Preamble to Resolution 1315 'that persons who commit or authorize serious violations of international humanitarian law are individually responsible and accountable for those violations and that the international community will exert every effort to bring those responsible to justice in accordance with international standards of justice, fairness and due process of law..." 53

The above ruling of the Court was a reiteration of not only the global community's stance on ending impunity, but also the intent of the Court to carry out its mandate of prosecuting the perpetrators for the crimes allegedly

${ }^{48}$ Prosecutor v Omar Serushago, Case No ICTR 98-39-T, Decision Relating to Guilty Plea 14 December 1998, para 41

49 Prosecutor v Brima, Kamara and Kanu Case No. SCSL 04-16-T, Trial Judgement 28 June 2007

${ }^{50}$ Para 127 of the Court's Practice Direction, “““....The Practice Direction provides for a wide range of allowances to be paid to witnesses testifying before the Special Court. These include an attendance allowance as compensation for earnings and time lost as a result of testifying, accommodation, meals transport, medical treatment, childcare and other allowances."

${ }^{51}$ Paragraph 129 further reads, "Relocation to another country is a protection measure employed by WVS pursuant to its responsibility to provide protection for witnesses and victims who are at risk on account of the testimony given by them" 51

${ }^{52}$ Prosecutor v Taylor, Case No. SCSL-03-01-I, Decision on Immunity from Prosecution, 31 May 2004

${ }^{53}$ Prosecutor v Taylor, Case No. SCSL-03-01-I, Decision on Immunity from Prosecution, 31 May 2004, para 39 
committed, which fell within its jurisdiction. However, the Prosecutors were disinclined to acting this out, and the Chambers would only adjudicate on cases that were presented at court. Had these leaders who were alleged to have committed crime been prosecuted, maybe the argument that the Court did not prosecute enough leaders for the crimes committed in the eleven year civil war may not have been so pronounced. By not prosecuting these leaders, victims were also denied justice, and justice for the victims remains the paramount objective for instituting such tribunals, as well as to provide deterrent for potential perpetrators, in as much as punishing the perpetrators.

\section{Conclusion}

The crimes committed during Sierra Leone's brutal eleven year civil war saw the establishment of the Special Court for Sierra Leone in 2002. The Court's mandate under UN Security Council Resolution 1315(2000) was aimed at prosecuting those individuals who bear the greatest responsibility of serious offences under international humanitarian and Sierra Leone laws, including the leaders who had threatened the peace process.

In the absence of evidence to assist international courts or tribunals during trials, the testimony of insider witnesses is crucial, as their testimony might provide significant information on the crimes and the persons who allegedly committed them. The earliest tribunals of the ICTY and ICTR had established that even if insider witnesses cooperated with the prosecution, they themselves should not escape punishment. In the case where the court use a leader as an insider witness, that would not exempt that leader from punishment. A case in point is that of Jean Kambanda at the ICTR, though he cooperated with the prosecution, he nevertheless received the maximum punishment of a life sentence for the crimes he committed.

At the Special Court for Sierra Leone, the Prosecutor's strategy involved engaging leaders as insider witnesses, without prosecuting them. In the process, these leaders evaded punishment for the alleged crimes they themselves committed or authorised. The departure from international good practice established by earlier tribunals could be interpreted as a missed opportunity for the Court to accomplish its mandate of holding to account "those who bear the greatest responsibility," of the crimes committed during the Sierra Leone conflict, which offended international humanitarian and Sierra Leone laws, as provided for under UN Security Council Resolution 1315(2000).

Furthermore, by not punishing those leaders for the heinous crimes they allegedly committed, the concerted effort of the global community to hold to account individuals who commit serious crimes during conflict may have been thwarted. This therefore leads to the inevitable conclusion that the Court may have legitimised impunity, thereby failing to align to the position of the 
global community including that of the UN as well as the government of Sierra Leone.

\section{References:}

1. Ainley K, Friedman R and Mahony C. ' Evaluating Transitional Justice, Accountability and Peacebuilding in Post- Conflict Sierra Leone' (First Published 2015 by MACMILLAN PALGRAVE)

2. Articles 1(1), 4(b) and 14(1) of the Statute of the Special Court for Sierra Leone

3. Courtney III, R. ' INSIDERS AS COOPORATING WITNESES: OVERCOMING FEAR AND OFFERING HOPE'p.39. http://www.unafei.or.jp/english/pdf/PDF_GG4_Seminar/Fourth_GG Seminar_P36-46.pdf

4. De Brouwers AM, and Smeulers A, 'The Elga Companion to the International Criminal Tribunal of Rwanda. ' (Edward Elgar Publishers, 2016)

5. Del Ponte, C, with Sudetic, C, ' Madame Prosecutor Confrontations with Humanity's Worst Criminals and the culture of Impunity' (Published 2008, Other Press New York)

6. International Humanitarian Law, Data Base, < https://ihldatabases.icrc.org/customaryihl/eng/print/v1_cha_chapter44_rule158>

7. Kaldor M, with Vincent J, 'United Nations Development Programme Evaluation Office`, EVALUATION OF UNDP ASSISTANCE TO CONFLICT AFFECTED COUNTRIES; CASE STUDY SIERRA LEONE. (2006)

8. KELSALL T, ' CULTURE UNDER CROSS-EXAMINATION: INTERNATIONAL JUSTICE AND THE SPECIAL COURT FOR SIERRA LEONE` (Published 2009, Cambridge University Press)

9. President of the Republic of Sierra Leone, Annex to the letter dated 12 June 2000, addressed to the President of the Security Council, U.N. Doc. S/2000/786/ http://www.rscsl.org/Documents/Establishment/S-2000-786.pdf

10. Prosecutor v Brima, Kamara and Kanu (AFRC Trial), Case No. SCSL 04-16-T, Trial Judgement 28 June 2007

11. Prosecutor v Charles Taylor (Taylor Trial), Case No. SCSL 03-01

12. Prosecutor v Dragan Zelenovic Case No. IT-96-23/2

13. Prosecutor v. Fofana, Case No. SCSL-04-14-PT (Preliminary Defence Motion- Matters Requiring Factual Determination), 3 March 2004

14. Prosecutor v Jean Kambanda, Case No. ICTR 99-54-A-T

15. Prosecutor v Miroslav Bralo Case No. IT-95-17 820 
16. Prosecutor v Norman, Fofana and Kondewa (CDF Trial), Case No. SCSL 04-14

17. Prosecutor v Omar Serushago, Case No ICTR 98-39-T, Decision Relating to Guilty Plea 14 December 1998

18. Prosecutor v Predrag Banovic Case No. IT-02-65-1

19. Prosecutor v Sesay, Kallon and Gbao (RUF Trial), Case No. SCSL04-15

20. Prosecutor v Taylor, Case No. SCSL-03-01-I, Decision on Immunity from Prosecution, 31 May 2004

21. Prosecutor v Taylor, Case No. SCSL-03-01-I, Decision on Immunity from Prosecution, 31 May 2004

22. Schabas W: The UN International Criminal Tribunals The former Yugoslavia, Rwanda and Sierra Leone' (First Published 2006, Cambridge University Press)

23. The Special Court for Sierra Leone and the Residual Special Court for Sierra Leone, Website http://www.rscsl.org/

24. The United Nations Security Council Resolution, '1315(2000) UN Doc. S/RES/1315(2000), 2000. http://www.rscsl.org/Documents/Establishment/S-Res-1315-2000.pdf

25. TRC report. Volume Two, Chapter Two .http://www.sierraleonetrc.org/index.php/view-report-text-vol2/item/volume-two-chapter-two?category_id=20

26. United Nations International Criminal Tribunal for the former Yugoslavia. Website page on 'Witnesses`

27. United Nations Secretary General Bank Ki-Moon,Address;KampalaUgandaon,31May2010<http://www.un.org/africarenewal/webfeatures/secretary-general $\%$ E2\%80\%99s-\%E2\%80\%9C-ageaccountability\%E2\%80\%9D-address-icc-review-conference

28. UNITED STATES INSTITUTE OF PEACE. Peace Agreement Digital Collection, Sierra Leone (March 2002) >> Peace Agreement.https://www.usip.org/sites/default/files/file/resources/coll ections/peace_agreements/sierra_leone_11301996.pdf

29. Wigglesworth G, 'The End of Impunity? Lessons from Sierra Leone (July 2008), http://onlinelibrary.wiley.com/doi/10.1111/j.14682346.2008.00738.x/abstract 